\title{
Communication
}

\author{
[Comunicação]
}

\section{Adulterants interference on Fourier Transform Infrared analysis of raw milk}

\author{
[Interferência de adulterantes na análise do leite cru por espectroscopia pela \\ transformada de Fourier] \\ D.C.S.Z. Ribeiro, W.L.F. Tavares, M.O. Leite, M.O.P. Cerqueira, J.S. Lima, \\ L.F. Ferreira, F.A.C. Feijo, J.P. Haddad, L.M. Fonseca*
}

Universidade Federal de Minas Gerais - Belo Horizonte, MG

\begin{abstract}
Milk is one of the most complete foods in nature, with high nutritive value and characteristic physical-chemical, sensorial, and microbiological properties. The physicalchemical analysis is a tool to evaluate its value or the industrial yield as well as to detect possible milk frauds (Silva, 2013).
\end{abstract}

Usual major milk composition is of $87.3 \%$ water, $4.6 \%$ lactose, $3.25 \%$ protein, $3.9 \%$ fat, $12.7 \%$ total solids, and non-fat $8.8 \%$ solids. Knowledge of milk components and characteristics is the basis for tests that are designed to investigate modified milk composition. Substantial reduction of solid components could, for example, indicate the fraudulent addition of water to the milk. Altogether, adulteration and variations due to factors such as lactation stage, breed, feeding, environmental temperature, management, milking interval, production and mammary gland health may affect milk composition (Brito et al., 2016). Optimal composition is a preponderant factor for the dairy industry, in processes such as cheese, butter, powdered milk, milk cream, cream cheese and other products (Leite, 2006).

Milk components, and particularly fat and protein are important for quality and integrity determination. Additional analyses for somatic cell count (SCC) and individual bacteria counting are complementary for this quality measurement (Brandão et al., 2010; Oliveira et al., 2012).

Factors such as age of sample, transport conditions and use of preservatives may interfere in the quality evaluation. For example, bronopol is a preservative added to the raw milk sample to avoid quality loss; usually samples may be kept ten days at temperatures up to $10^{\circ} \mathrm{C}$ (Leite, 2006). However, other authors have reported decrease in milk fat concentration after seven days, and slight modifications in protein and total solids concentration after storage of six days (Ribas et al., 2004).

In Brazil, new variables were legalized to ensure a minimum standard to be met by all milk producers (Brasil, 2002; 2011; 2016). Several solid components, IBC, SCC, and drug residues were included in this new regulation for at least monthly monitoring of producers linked to dairies under Federal Inspection. A national net of laboratories was also created to respond to the growing analytical demand (Rede Brasileira de Laboratórios de Análise da Qualidade do Leite; RBQL). These labs are configured with modern electronic equipment for quick and precise analysis, to provide milk quality information in the adequate time (Silveira et al., 2004).

Raw milk must present the original composition, and any component withdrawal, or addition of water, preservatives, contaminants, or any other substance to the raw milk is illegal. The consequence of fraud is consumer misleading and risks including health issues, illegal competition, economical and marketing unbalance. One outstanding example took place in China, where a widespread fraud with melamine addition to raw milk happened in 2008. The outcome was the death of six and more than 300,000 people were sickened.

Recebido em 23 de janeiro de 2017

Aceito em 16 de maio de 2018

E-mail: leorges@ufmg.br 
Melamine was added with the intent to artificially increase the protein levels to disguise water illegally added to raw milk (Silva, 2013).

Similar incidents have come to light in the last years in Brazil, with several cases of systematic adulteration being detected in inspected dairy industries. Common aspects of these cases included water addition to the raw milk together with substances to counterbalance properties modification of the milk due to the extraneous water. For example, to restore density and freezing point, salt, sugar, and other substances are used. Impairment of the milk nutritional value is a direct consequence of these frauds. Additionally, preservative is illegally added to decrease microbial growth in low quality raw milk (Rosa-Campos et al., 2011; Santos et al., 2013; Silva, 2013; Abrantes et al., 2014).

Although several analytical methods have been used for a long time to investigate raw milk adulteration in the dairy industry, usually they are time consuming and expensive. However, equipments with relatively low analytical cost have been developed in recent decades. Mid infrared equipment, for example, has expanded the analytical capacity for compositional analysis, while flow cytometers have been used for somatic cell and bacterial counting in raw milk (Oliveira et al., 2012).

The infrared equipment is based in differential IR absorption in specific wavelengths of chemical groups present in fat, protein, and lactose in milk (Biggs et al., 1987). For milk, the mid infrared spectrum (MIR) represents great advantages when compared to previous techniques, as the simultaneous reading of several milk components, without any previous sample treatment, with high output and possibility of process automation (RodriguezOtero et al., 1997). The IR technique matched the reference methods (Silveira et al., 2004), with major milk components being simultaneously analyzed.

The automated routine analysis of raw milk with electronic equipment usually includes the main milk components total solids, fat, protein, casein, ureic nitrogen, and lactose among others through IR analysis, and somatic cells and bacterial counting by flow cytometry. Nowadays, old IR equipment based on filters are being replaced by
FTIR based equipment, a new and promising technology (Oliveira et al., 2012).

Although the infrared methods have been extensively evaluated for milk quality analysis, not much has advanced in the study of extraneous substances used as adulterant in milk. One of the concerns is related to the potential interference of these substances in the analysis of milk components because of superimposed absorptive wavelengths. Moreover, since the current methods used to detect adulterants in raw milk are relatively expensive, highly dependent on labor and time-consuming, innovative screening methods to simultaneously detect extraneous substances added to milk would represent an expressive advance in the dairy sector.

The objective of the current work was to evaluate the potential interference of extraneous substances, added to milk as adulterants, in the component analysis based on Fourier Transform Infrared technique.

Six batches of bulk tank raw milk were obtained from August to October 2016, from healthy cows, under veterinary supervision. To each batch sucrose was added $(0.1 \mathrm{~g} / 100 \mathrm{~mL}$; $0.5 \mathrm{~g} / 100 \mathrm{~mL}$ and $1 \mathrm{~g} / 100 \mathrm{~mL})$ or starch $(0.1 \mathrm{~g} / 100 \mathrm{~mL} ; 0.5 \mathrm{~g} / 100 \mathrm{~mL}$ and $1 \mathrm{~g} / 100 \mathrm{~mL})$ and aliquoted in $50 \mathrm{~mL}$ vials. Samples for compositional analysis and somatic cell counts were added with bronopol, and for bacterial counting with azidiol.

Samples were stored during 3, 24, 48, 72, and 168 hours at $7^{\circ} \mathrm{C} \pm 2^{\circ} \mathrm{C}$ and $25 \pm 2^{\circ} \mathrm{C}$. The number of samples were 1008 (six batches $\mathrm{x}$ two adulterants $\mathrm{x}$ three concentrations $\mathrm{x}$ six storage time $\mathrm{x}$ two storage temperatures $\mathrm{x}$ two preservatives; and 144 samples as control) (Ribas et al., 2004; Leite, 2006; Rosa-Campos et al., 2011).

Compositional analyses were done by FTIR $400 \AA$ (LactoScope FTIR, Delta Instruments, Drachten, Netherlands) and some spectra are shown in Figure 1. Somatic cell count by flow cytometry in FTIR 400® (SomaScope, Delta Instruments, Drachten, Netherlands) and total bacterial counting by flow cytometry in Bactoscan FC® (Foss, Hillerod, Denmark). Multiple Linear Regression was used for 
statistical analysis with a confidence interval of 95\%, using the program Stata version 12.0 (Stata..., 2011).

Milk analyzed for SCC and TBC were monitored to ensure IR readings deviations for components were not due to quality issues. However, starch and sucrose additon affected both values. Starch addition resulted in increasing SCC and TBC, while sucrose addition resulted in reducing SCC readings (Table 1).

Storage time was an influential factor, with SCC reduction after $24 \mathrm{~h}$, but this effect was more pronounced with storage at $25 \pm 2{ }^{\circ} \mathrm{C}$ and starch addition. Previous report by Leite (2006), in raw milk without adulterants, has found SCC reduction storage at $30^{\circ} \mathrm{C}$ during five days, while TBC increased. In the current work, TBC increased was noticed in the seventh day of storage at $25^{\circ} \mathrm{C}$.

Every experimental repetition presented extremely low p-values for the all dependent variables, except for TBC, which was significant only in the last repetition. This indicates the strict control of the milk used in the experiment, once the variables that could adversely affect the compositional results outcome, such as lactation stage, calving order, milking management and hygiene, feeding, among others were controlled in the experimental repetitions (Brito et al., 2016). Similarly, high Adjusted $R^{2}$ value was found for all dependent variables, except for TBC in the milk added with sucrose treatment. This indicates that the multiple linear regression was well adjusted to the sample data (Triola, 2008).

Composition results for milk added with starch deviated from the control with increase of parameters fat, protein, lactose, total solids, solids non fat and reduction of casein and MUN using FTIR $(\mathrm{P}<0.05)$. However, the addition of sucrose to milk modified FTIR results for lactose, TS, SNF and MUN with increasing these values and decreasing protein and casein (Table 2).

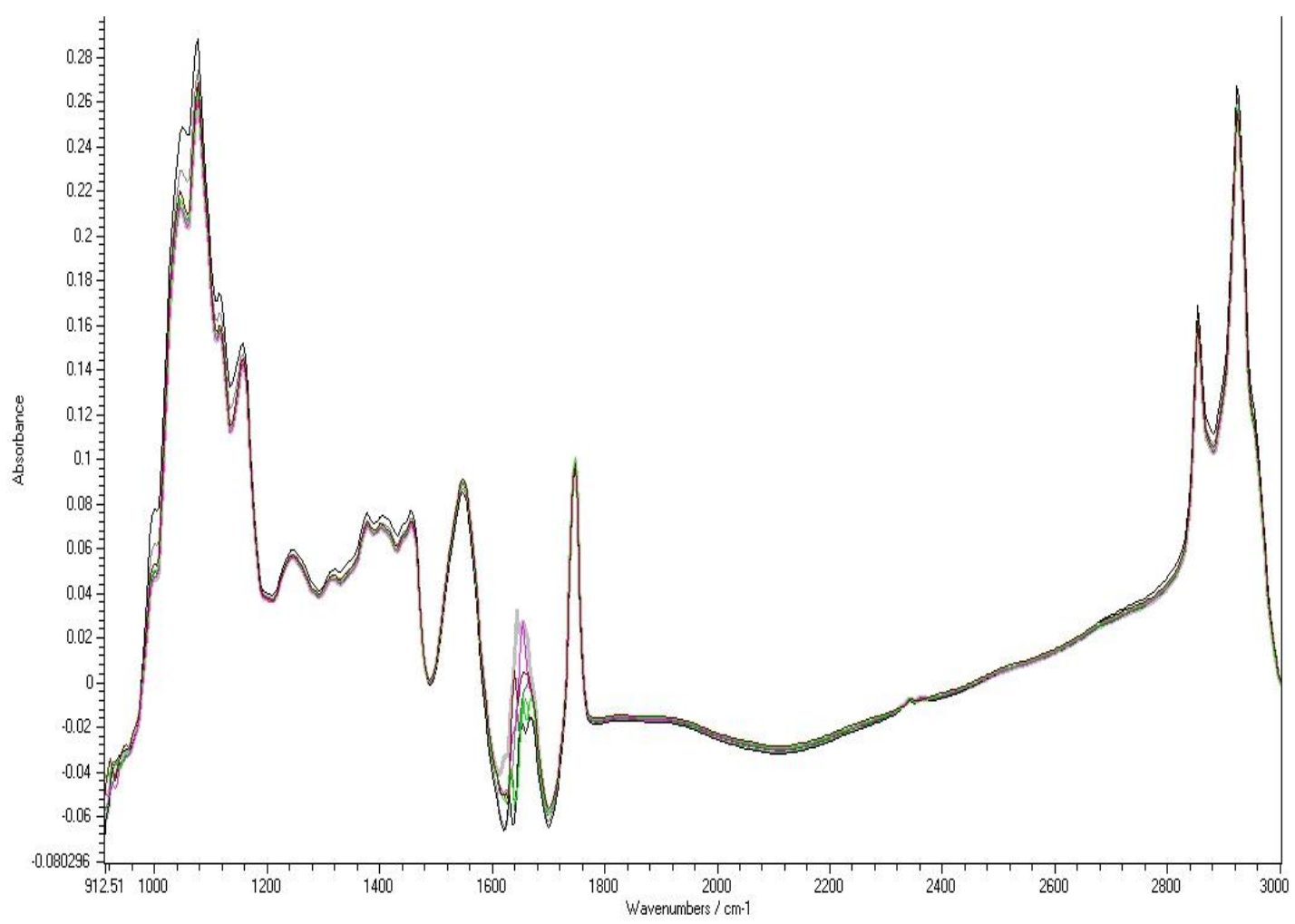

Figure 1. FTIR spectra of milk control and added starch and sucrose, in three different concentrations. 
Table 1. Mean and standard deviation (sd) of the SCC and TBC in raw milk added with starch and sucrose and analyzed by flow cytometry

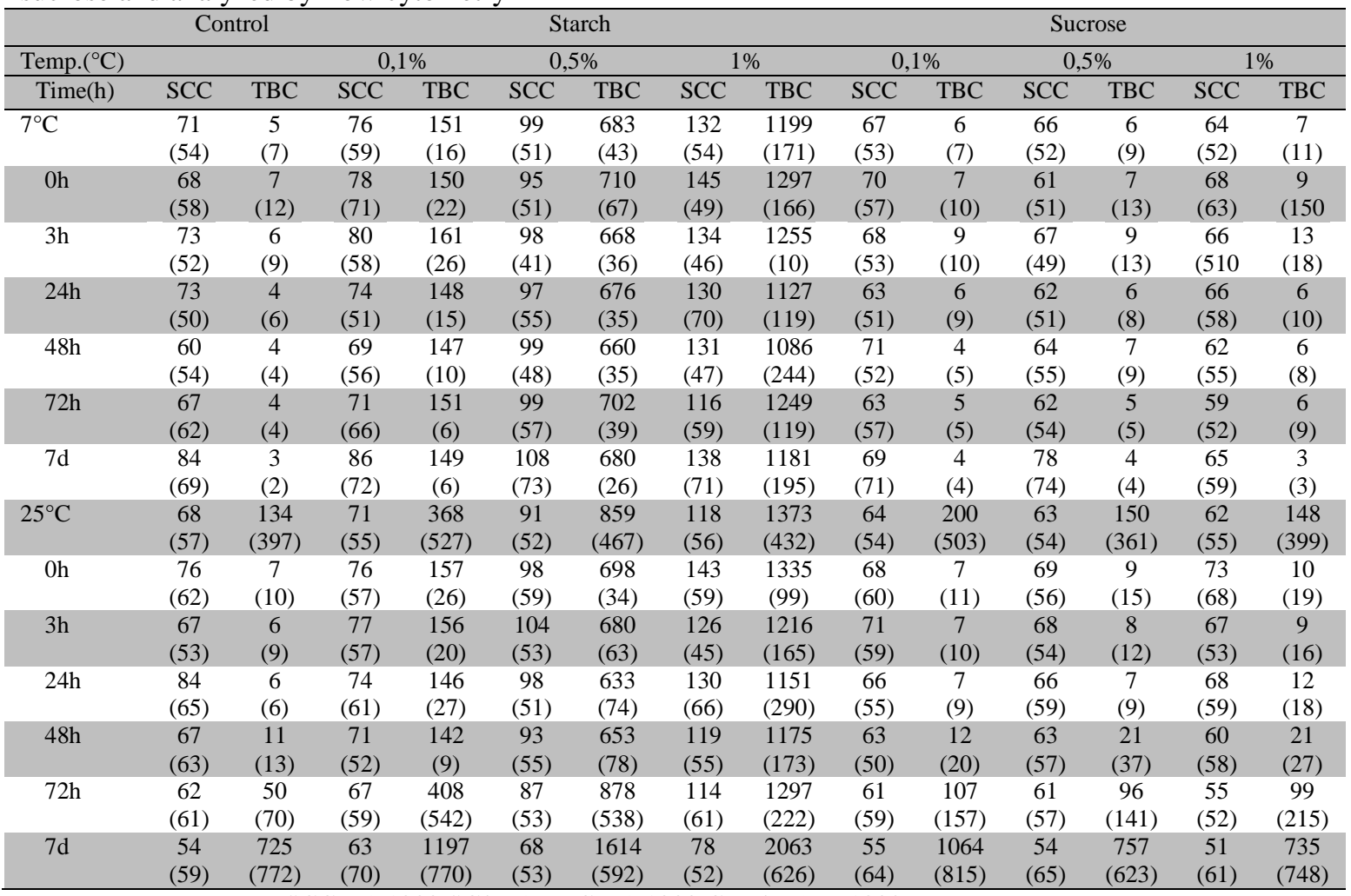

Temp.: temperature SCC $-(x 1000 \mathrm{SC} / \mathrm{mL}) \mathrm{TBC}-(\mathrm{x} 1000 \mathrm{CFU} / \mathrm{mL}) \mathrm{n}=1008$.

Table 2. Mean and standard deviation (sd) of the physical chemical parameters of raw milk added with starch and sucrose analyzed by FTIR

\begin{tabular}{|c|c|c|c|c|c|c|c|c|}
\hline & & \multirow[t]{2}{*}{ Control } & \multicolumn{3}{|c|}{ Starch } & \multicolumn{3}{|c|}{ Sucrose } \\
\hline & & & $0,1 \%$ & $0,5 \%$ & $1 \%$ & $0,1 \%$ & $0,5 \%$ & $1 \%$ \\
\hline \multirow[t]{2}{*}{ Fat $(\mathrm{g} / 100 \mathrm{~g})$} & $7^{\circ} \mathrm{C}$ & $3,35(0,32)$ & $3,38(0,33)$ & $3,41(0,34)$ & $3,44(0,36)$ & $3,37(0,32)$ & $3,35(0,31)$ & $3,35(0,32)$ \\
\hline & $25^{\circ} \mathrm{C}$ & $3,37(0,32)$ & $3,40(0,34)$ & $3,43(0,34)$ & $3,44(0,36)$ & $3,37(0,32)$ & $3,37(0,32)$ & $3,36(0,33)$ \\
\hline \multirow[t]{2}{*}{ Protein $(\mathrm{g} / 100 \mathrm{~g})$} & $7^{\circ} \mathrm{C}$ & $3,35(0,03)$ & $3,36(0,03)$ & $3,36(0,03)$ & $3,37(0,03)$ & $3,35(0,03)$ & $3,34(0,03)$ & $3,33(0,03)$ \\
\hline & $25^{\circ} \mathrm{C}$ & $3,35(0,04)$ & $3,36(0,03)$ & $3,36(0,03)$ & $3,37(0,03)$ & $3,35(0,03)$ & $3,34(0,03)$ & $3,33(0,03)$ \\
\hline Lactose $(\mathrm{g} / 100 \mathrm{~g})$ & $7^{\circ} \mathrm{C}$ & $4,65(0,06)$ & $4,67(0,06)$ & $4,71(0,06)$ & $4,77(0,06)$ & $4,70(0,06)$ & $4,92(0,06)$ & $5,19(0,05)$ \\
\hline \multirow[t]{2}{*}{ TS $(g / 100 g)$} & $7^{\circ} \mathrm{C}$ & $12,32(0,30)$ & $12,37(0,32)$ & $12,45(0,33)$ & $12,54(0,34)$ & $12,39(0,30)$ & $12,56(0,30)$ & $12,80(0,31)$ \\
\hline & $25^{\circ} \mathrm{C}$ & $12,35(0,31)$ & $12,40(0,33)$ & $12,48(0,33)$ & $12,54(0,35)$ & $12,40(0,31)$ & $12,59(0,31)$ & $12,82(0,32)$ \\
\hline \multirow[t]{2}{*}{$\mathrm{SNF}(\mathrm{g} / 100 \mathrm{~g})$} & $7^{\circ} \mathrm{C}$ & $9,01(0,07)$ & $9,03(0,08)$ & $9,09(0,08)$ & $9,15(0,08)$ & $9,06(0,08)$ & $9,28(0,08)$ & $9,55(0,08)$ \\
\hline & $25^{\circ} \mathrm{C}$ & $9,01(0,08)$ & $9,04(0,08)$ & $9,09(0,08)$ & $9,16(0,08)$ & $9,07(0,08)$ & $9,28(0,08)$ & $9,55(0,08)$ \\
\hline MUN (mg/dL) & $7^{\circ} \mathrm{C}$ & $14,53(1,94)$ & $14,36(2,07)$ & $10,55(2,04)$ & $5,14(2,92)$ & $14,80(2,00)$ & $15,04(1,97)$ & $14,92(1,69)$ \\
\hline \multirow[t]{2}{*}{$\mathrm{FP}\left({ }^{\circ} \mathrm{C}\right)$} & $7^{\circ} \mathrm{C}$ & $-0,530(0,01)$ & $-0,532(0,01)$ & $-0,537(0,01)$ & $-0,543(0,01)$ & $-0,535(0,01)$ & $-0,555(0,01)$ & $-0,580(0,01)$ \\
\hline & $25^{\circ} \mathrm{C}$ & $-0,531(0,01)$ & $-0,533(0,01)$ & $-0,538(0,01)$ & $-0,543(0,01)$ & $-0,536(0,01)$ & $-0,556(0,01)$ & $-0,580(0,01)$ \\
\hline
\end{tabular}

n=504; FTIR: Fourier Transform Infrared; TS: total solids; SNF: solids nonfat; MUN: milk urea nitrogen; FP: freezing point. 
Lactose IR readings were slightly higher in milk added with starch, however, after sucrose addition, lactose content readings reached values as high as $5.19 \%$ (Table 2).

Freezing point of milk decreased with increasing sucrose concentration, and this is due to the increased amount of soluble substance. As a colligative property, the freezing point is correlated to the vapour pressure at the solution according to Raoult's Law. On the other hand, since starch molecules are longer and have higher molecular weight than sucrose, it is expected that starch addition to the milk will have lesser effect on freezing point.

The use of sucrose and starch as milk adulterants is a very common fraud. For example, RosaCampos et al. (2011) analyzed 72 pasteurized milk samples and in some cases found sucrose addition in $100 \%$ of some brands samples.

MUN values obtained by IR were lower $(\mathrm{P}<$ $0.05)$ after starch addition, even during storage at $7^{\circ} \mathrm{C}$ and $25^{\circ} \mathrm{C}$. On the other hand, MUN values slightly increased in the control group during storage. Casein results were lower in milk added with starch or sucrose than in control milk.

In conclusion, infrared analysis of raw milk added with extraneous substances used as adulterants presented deviating results for component analysis due to superimposed absorptive wavelengths.

Starch addition changed expected compositional results of raw milk in a different direction and intensity when compared with sucrose, with interference in the major components, fat and protein. Simultaneously, increasing individual bacterial count by flow cytometry were obtained after starch addition.

Keywords: raw milk, FTIR, startch, sucrose, composition analysis

\section{ACKNOWLEDGEMENTS}

Fapemig $\quad-\quad$ APQ1179-14; $\quad$ CNPq PQ309801/2014-1

\section{RESUMO}

O objetivo deste trabalho foi analisar as leituras de composição do leite cru por meio de espectrofotometria FTIR, utilizando-se curva de regressão PLS, bem como as contagens de células somáticas e bacteriana total por citometria de fluxo, após adição de amido e sacarose. O leite cru foi adulterado com três concentrações de amido e sacarose (0,1\%, 0,5\% e 1\%), colocado em frascos contendo bronopol ou azidiol, os quais foram armazenados em duas temperaturas $\left(7 \pm 2{ }^{\circ} \mathrm{C}\right.$ e $\left.25 \pm 2^{\circ} \mathrm{C}\right)$. As análises foram realizadas após zero, três, 24, 48, 72 e 168 horas de armazenamento. O modelo de regressão linear múltipla foi utilizado para análise estatística. A adição de amido e sacarose resultou em mudança significativa $(P<0,05)$ para todas as variáveis dependentes. O leite adulterado com amido resultou em aumento nas leituras de gordura, proteína, lactose, sólidos totais (ST), sólidos não gordurosos (SNG), CCS e CBT e em diminuição das leituras de caseína, do nitrogênio ureico do leite (NUL) e do ponto de congelamento. O leite adulterado com sacarose resultou no aumento das leituras da lactose, ST, SNG e NUL, enquanto as leituras de proteína, caseína, ponto de congelamento e CCS diminuíram. Este trabalho evidencia a importância do monitoramento de adulterantes reconstituintes no leite por afetarem os resultados analíticos da qualidade do leite, obtidos por métodos eletrônicos.

Palavras-chave: leite cru, FTIR, amido, sacarose, análise composicional

\section{REFERENCES}

ABRANTES, M.R.; CAMPÊLO, C.S.; SILVA, J.B.A. Fraude em leite: métodos de detecção e implicações para o consumidor. Rev. Inst. Adolfo Lutz, v.73, p.244-251, 2014.
BIGGS, D.A.; JOHNSSON, G.; SJAUNJA, L.O. Analysis of fat, protein, lactose and total solids by infra-red absorption. In: monograph on rapid indirect methods for measurement of the major components of milk. Bull. Int. Dairy Fed., n.208, p.21-29, 1987. 
BRANDÃO, M.C.M.P.; CARMO, A.P.; BELL, M.J.V. et al. Characterization of milk by infrared spectroscopy. Rev. Inst. Latic. Cândido Tostes, v.65, p.30-33, 2010.

BRASIL. Ministério da Agricultura, Pecuária e Abastecimento. Instrução Normativa n.51, de 18/09/2002. Aprova os regulamentos técnicos de produção, identidade e qualidade do leite tipo A, do leite tipo $\mathrm{B}$, do leite tipo $\mathrm{C}$, do leite pasteurizado e do leite cru refrigerado e o regulamento técnico da coleta de leite cru. Diário Oficial da União, Brasília, 20 set. 2002. Seção I, p.13.

BRASIL. Ministério da Agricultura, Pecuária e Abastecimento. Instrução Normativa n.62, de 29/12/2011. Aprova o Regulamento Técnico de Identidade e Qualidade do leite tipo A, o Regulamento Técnico de Identidade e Qualidade do leite cru refrigerado, o Regulamento Técnico de Identidade e Qualidade do leite pasteurizado e o Regulamento Técnico da Coleta de Leite Cru Refrigerado e seu transporte a granel. Diário Oficial da União, Brasília, 30 dez. 2011b. Seção I, p.6.

BRASIL. Ministério da Agricultura, Pecuária e Abastecimento. Instrução Normativa n.7, de 03/05/2016. Altera o Regulamento Técnico de Identidade e Qualidade do leite tipo A, o Regulamento Técnico de Identidade e Qualidade do leite cru refrigerado, o Regulamento Técnico de Identidade e Qualidade do leite pasteurizado e o Regulamento Técnico da Coleta de Leite Cru Refrigerado e seu transporte a granel. Diário Oficial da União, Brasília, 04 mai. 2016. Seção I, p.11.

BRITO, M.A.; BRITO, J.R.; ARCURI, E. et al. 2016. Composição do leite. Disponível em: <http://www.agencia.cnptia.embrapa.br/Agencia 8/AG01/arvore/AG01_128_21720039243.html>. Acessado em: 02 dez. 2016.

LEITE, M.O. Fatores interferentes na análise eletrônica da qualidade do leite cru conservado com azidiol líquido, azidiol comprimido $e$ bronopol. 2006. 63f. Tese (Doutorado em Medicina Veterinária) - Escola de Veterinária, Universidade Federal de Minas Gerais, Belo Horizonte, MG.
OLIVEIRA, M.C.P.P.; SILVA, N.M.A.; BASTOS, L.P.F. et al. Fourier Transform Infrared Spectroscopy (FTIR) for MUN analysis in normal and adulterated milk. Arq. Bras. Med. Vet. Zootec., v.64, p.1360-1366, 2012.

RIBAS, N.P.; HARTMANN. W.; MONARDES, H.G. et al. Sólidos totais do leite em amostras de tanque nos Estados do Paraná, Santa Catarina e São Paulo. Rev. Bras. Zootec., v.33, Supl.3, p.2343-2350, 2004

RODRIGUEZ-OTERO, J.L.; HERMIDA, M.; CENTENO, J. Analysis of dairy products by nearinfrared spectroscopy: a review. J. Agrar. Food Chem., v.45, p.2815-2818, 1997.

ROSA-CAMPOS, A.A.; ROCHA J.E.S.; BORGO, L.A.; MENDONÇA, M.A. Avaliação físico-química e pesquisa de fraudes em leite pasteurizado integral tipo "c" produzido na região de Brasília, Distrito Federal. Rev. Inst. Latic. Cândido Tostes, v.66, p.30-34, 2011.

SANTOS, P.M.; PEREIRA-FILHO, E.R.; RODRIGUEZ-SAONA, L.E. Rapid detection and quantification of milk adulteration using infrared microspectroscopy and chemometrics analysis. Food Chem., v.138, p.19-24, 2013.

SILVA, L.C.C. Capacidade de detecção de adulterações e suficiência das provas oficiais para assegurar a qualidade do leite pasteurizado. 2013. 99f. Tese (Doutorado em Ciência Animal), Universidade Estadual de Londrina, Londrina, PR.

SILVEIRA, T.M.L.; FONSECA, L.M.; CANÇADO, S.V. et al. Comparação entre os métodos de referência e a análise eletrônica na determinação da composição do leite bovino. Arq. Bras. Med. Vet. Zootec., v.56, p.782-787, 2004.

STATA statistical software: release 12 . College Station, Texas: StataCorp LP. 2011.

TRIOLA, M.F. Introdução à estatística. 10.ed. Rio de Janeiro: LTC, 2008. 696p. 